\title{
Ústecké muzeum pískem zaváté
}

Zuzana Vařilová

\section{The Museum of Ústí nad Labem Buried in Sand}

Motto výstavy: Písek je běžnou, téměř každodenní součástí našeho života, presto o něm nevíme mnoho zajímavých věcí. Známe ho z břehù řek a potokì, z mořských pláži, pískoven, staveb a dětských hřišt'. Málokdo však tuší, jak pestré písky jsou, odkud vlastně pochází, co všechno se v nich zachovalo, jak vzácným materiálem se postupně stávají či jak překvapivě krásné mohou být pod mikroskopem...

Rok 2020 se nesl nejen v duchu koronavirové pandemie a $\mathrm{s}$ ní souvisejících obtíží, ale v Muzeu města Ústí nad Labem také ve znamení PÍSKU. Hlavním výstavním projektem roku 2020 byla totiž výstava pojmenovaná „,PÍSKY ZNÁMÉ
I NEZNÁMÉ aneb Fascinující svět obyčejného písku".

Spousta lidí se možná vyděsilo nebo alespoň nedůvěřivě kroutilo hlavou nad tím, že v honosné muzejní budově vystavujeme běžný písek namísto neokoukaných vzácných exponátů. Možná čekali písečnou hromadu tyčící se uprostřed sálu se zapíchnutou lopatou, nebo nějaké obří pískoviště. A tak zákonitě jedna z prvních otázek návštěvníků i mnohých novinářo byla: „Proč zrovna písek? Jak téma vzniklo a co vlastně bylo inspirací?" Pravdou je, že nápad udělat výstavu věnovanou výhradně písku krystalizoval pomalu po dobu několika let. Prvotním impulsem
RNDr. Zuzana Vařilová, Ph.D. Muzeum města Ústí nad Labem varilova@muzeumusti.cz

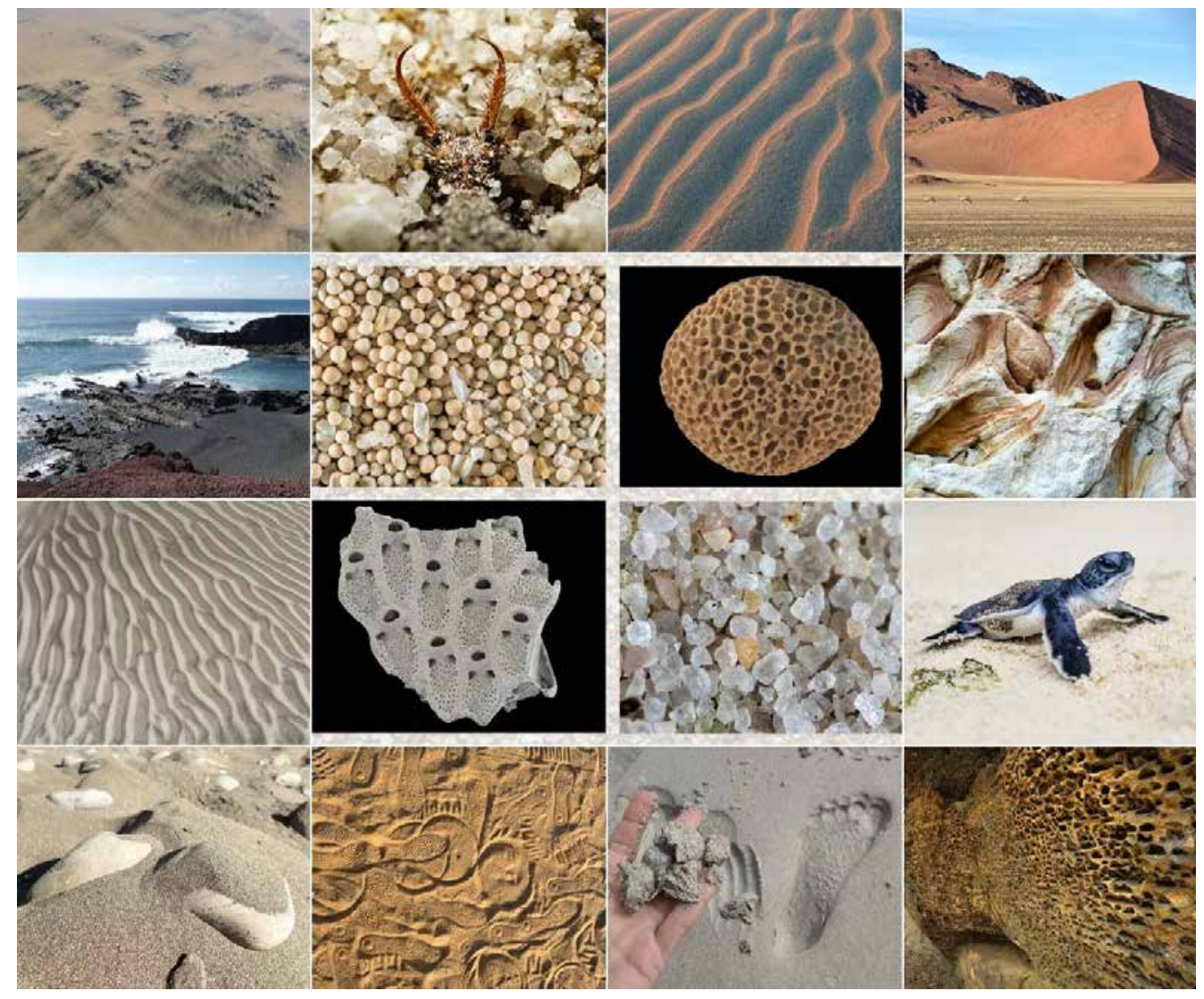

Rozmanitost námětů souvisejících s pískem je téměř nekonečná (mozaika fotografií z výstavy představující dílči témata) 
se stal projekt Petra Jana Juračky, který $\mathrm{v}$ rámci popularizace vědy nafotil pár písečných zrnek unikátní mikroskopickou metodou, a vznikla z toho malá umělecká díla. Dalším krokem bylo pak objevení webových stránek o písku „World Atlas of Sands", které založil nadšený sběratel písku Catalin Stefan z Drážd’an. Námět se pak postupně rozšiřoval o mnohá další témata. Výstava nakonec představila tento, na první pohled obyčejný materiál $\mathrm{z}$ různých úhlů pohledu - jako Písek pod mikroskopem, Písek neuvěritelně pestrý, Písek krajinotvorný, Život a stopy v písku, Písek užitečný, Písek jako klíč $k$ objevưm, Písek a pískovec ve službách člověka, Písek jako suvenýr, Písek meditační ad. Až v rámci příprav vyplynulo, jak je písečné téma neskutečně široké, že ani výstava v pěti sálech je nepokryje vyčerpávajícím způsobem.

Ke všem dílčím tématům bylo nutné dohledat maximum informací, získat kvalitní

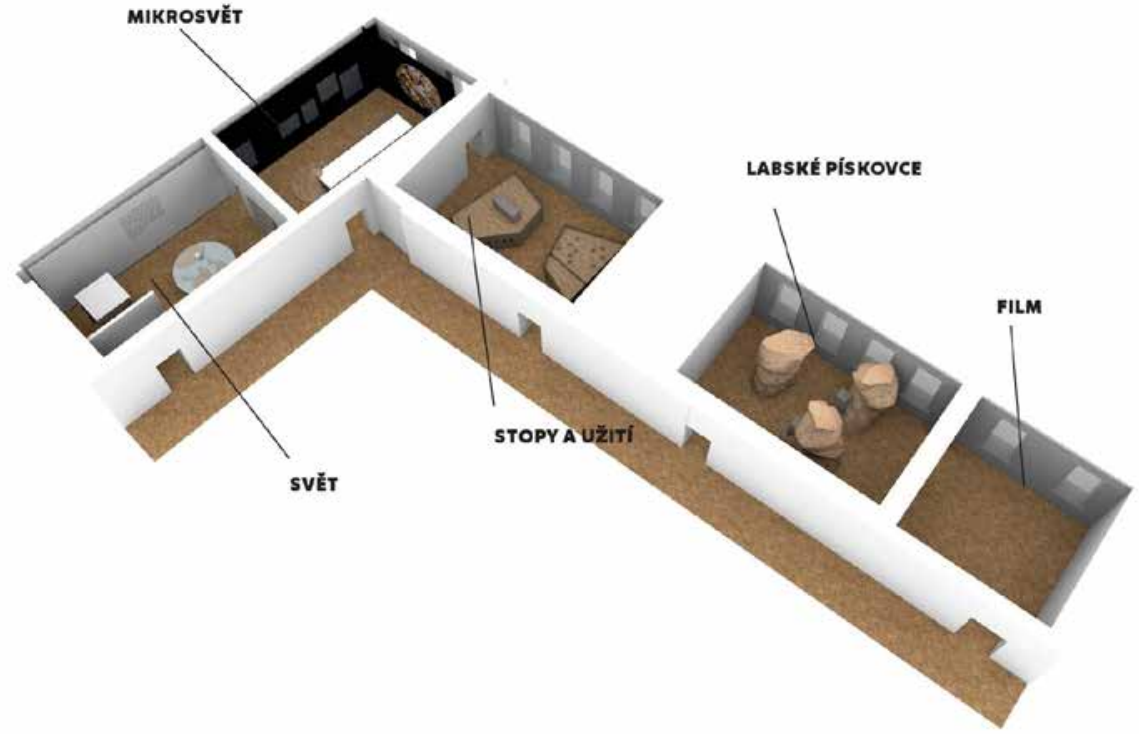

obrazovou dokumentaci a v neposlední řadě i reprezentativní písečné či pískovcové exponáty. Ke spolupráci byli osloveni nejen geologové, vybrané akademické a muzejní instituce, ale i kolegové a prátelé, kteří obětavě vozili pytlíky s pískem ze svých služebních cest i zahraničních dovolených.

Na zásadní otázku, jak vystavit písek poutavým způsobem, našel odpověd

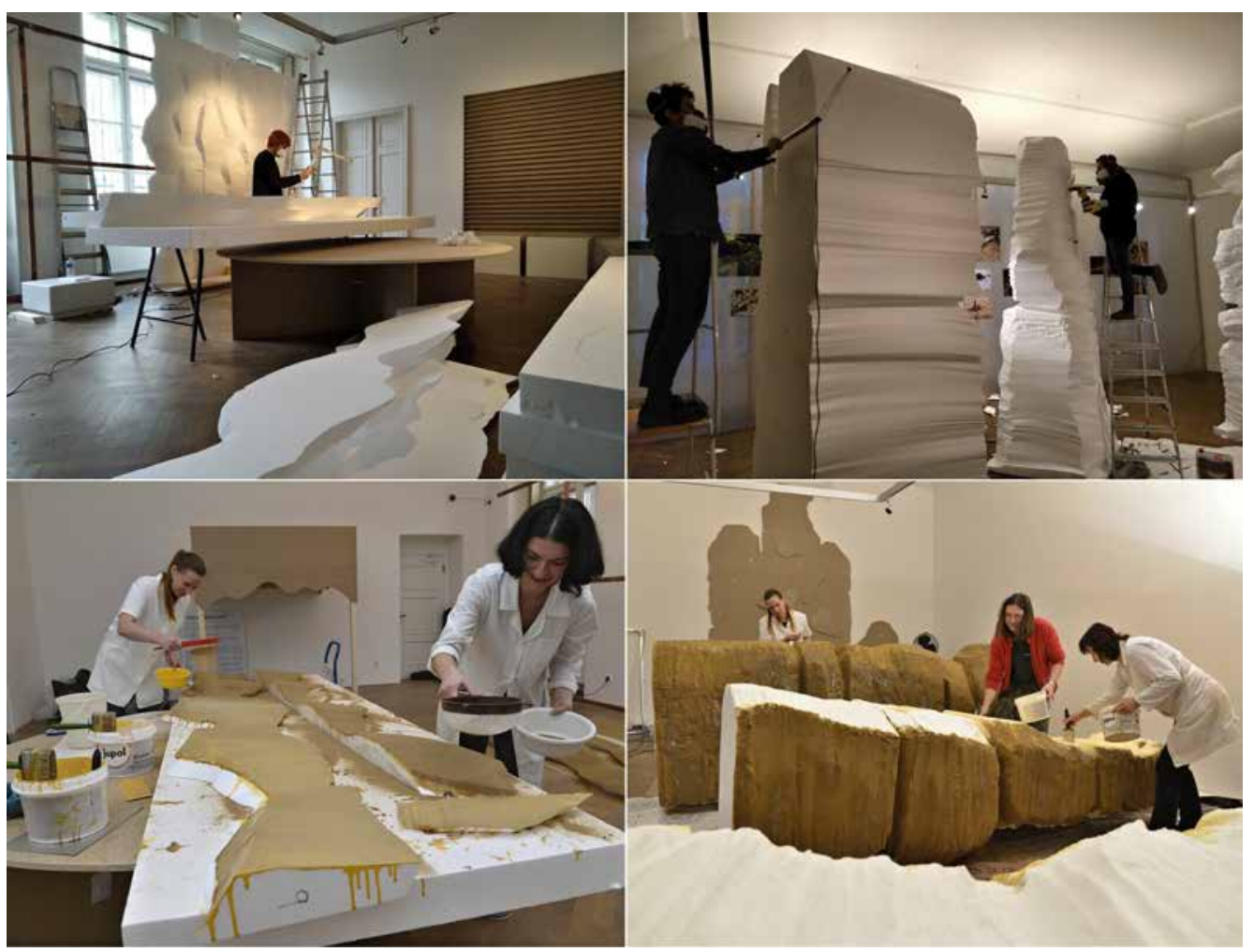

Vzniku tematických prvků a vestaveb (např. velkých písečných dun a pískovcových skalních věží) predcházely týdny tvořivé práce i náročných príprav (včetně "pískováni“), do nichž byly zapojeni vedle autorského týmu téměř všichni zaměstnanci muzea. foto: Z. Vařilová, J. Preclík, Muzeum města Ústí nad Labem, 2020 


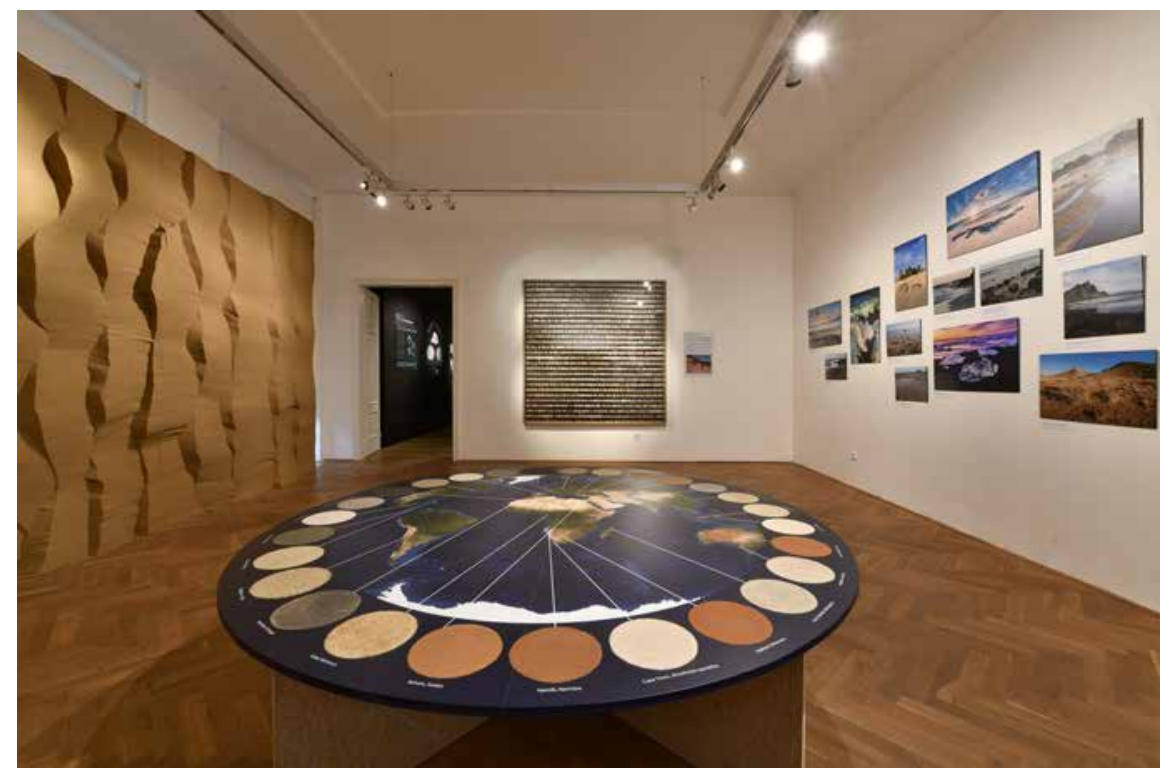

První výstavní sál s mapou se "sahacími" písky a vitrínou $s$ více než třemi tisíci vzorky písků z celého světa, sálu dominovala poušt nastojato (tvořená rovněž skutečným piskem) a malebné fotografie krajin s pisčitými akumulacemi. foto: J. Preclík, Muzeum města Ústí nad Labem, 2020 výtvarník Richard Loskot, se kterým naše muzeum dlouhodobě spolupracuje. Zhostil se této netradiční výzvy s tvưrčím zápalem sobě vlastním a vdechl písku estetický i hravý výstavní rozměr.

$\mathrm{Na}$ projektu se nakonec podílelo osm spoluautorů a přes dvacet autorů vystavených fotografií (včetně známých jmen jako Václav Sojka, Petr Juračka nebo Petr Berounský). Exponáty pocházely ze sbírek Muzea města Ústí nad Labem, Národního muzea v Praze, Moravského zemského muzea v Brně, Oblastního muzea v Děčíně, Správy Národního parku České Švýcarsko, Přírodovědecké fakulty Univerzity Karlovy v Praze a dalších šesti soukromých sbírek. Při realizaci výstavního projektu pomáhaly desítky dalších kolegů a spotřebováno bylo nepočítané množství písku.

Výstava byla otevřena koncem února 2020 a zůstala prodloužena až do počátku roku 2021. Přesto se na ní neštastný rok koronavirové pandemie nemile podepsal, zejména co se týká počtu příchozích. Ti štastnější, kteří ji stihli navštívit v době, kdy bylo muzeum otevřeno bez všemožných limitů a omezení, si ji mohli vychutnat a prožít se vším všudy. Výstava nebyla totiž jen pro odborníky, plná detailních faktografických informací - naopak! Naším cílem bylo představit toto neobvyklé téma především zábavnou formou, díky níž mohli návštěvníci zapojit téměř všechny smysly - nahlédnout do nekonečné pouště, prozkoumat vzorky písku pod mikroskopem, vyzkoušet si malování v písku, stopování zvírat, vlastní tvorbu z písku nebo horolezení v pískovcové krajině.

\section{Sto podob písku}

Překvapující pestrost a variabilitu písku našli návštěvníci v prvním výstavním sále, jehož součástí byla také dotyková mapa světa vytvořená ze skutečných, různě zrnitých a barevných písků z 27 lokalit ze všech koutů Země. Atmosféru dokreslovaly malebné fotografie pouští, romantických pláží a dalších oblastí, kde písky vznikají nebo se hromadí. Písek totiž tvoří podstatnou součást nezpevněných hornin zemského povrchu a odborníci z něj umí ledacos vyčíst. Někdy ho tvoří úlomky hornin nebo specifických minerálů, podle nichž lze určit, odkud materiál pochází. Velikost, tvar a míra opracování zrn vypovídají o transportu a podmínkách, ve kterých se písek usazoval. Mezi nejhojnější patří písek křemenný, existuje ale i celá řada dalších druhů písků - například zelené písky s převahou olivínu, černé písky tvořené převážně z pyroxenu, amfibolu, magnetitu anebo složené z úlomků sopečných hornin. Červenavé odstíny písku jsou zase typické pro pouštní oblasti. V tropických příbřežních oblastech se pak běžně vytvářejí písky karbonátové, ve kterých převládají zrna kalcitu nebo fragmenty vápnitých schránek mořských organismů.

Exponáty nejpočetnější a divácky nejatraktivnější byla pak obří stěnová vitrína naplněná 3193 vzorky písku z celého světa v malých skleněných lahvičkách. Jednalo se o podstatnou část kolekce již zmiňovaného Catalina Stefana z Drážd’an, kterému se podařilo během 13 let nashromáždit celkem 4800 druhů písků z 201 zemí. K nejcennějším vzorkům patří např. „hvězdný písek“ (star sand) z japonského souostroví Okinawa, písek ze vzdálených oblastí jako jsou třeba Svatý Kryštof a Nevis v Karibském moři či Cookovy ostrovy v jižním Tichém oceánu, písek z Antarktidy nebo z dalších oblastí, které je velmi obtížné navštívit, jako Severní Korea nebo Palestina. Tento unikátní soubor nejsou však jen tisíce malých lahviček naplněných pískem či drobným štěrkem, existuje $\mathrm{k}$ nim systematická databáze každý vzorek má identifikační číslo, je 
popsáno místo nálezu (stát, region/provincie, město/ostrov, lokalita souřadnice GPS a také zdroj písku). Původně číselně chronologicky seřazené vzorky musely být však pro výstavní účel nejprve přeskládány podle jednotlivých států (včetně výběru nejvhodnějších zástupců) a pak abecedně řazeny vedle sebe. A nechyběla zde samozřejmě ani Česká republika, kterou ve vitríně reprezentovalo kolem stovky vzorků různých druhů písku.

Nepřehlédnutelná byla „poušt' na stojáka" s mohutnými dunami, vytvořená rovněž pomocí skutečného písku, která dominovala prvnímu sálu podél jeho nejdelší stěny. Děti i dospělé pak pobavilo nakouknutí do tzv. "nekonečné pouště“, která byla důmyslně vytvořena ve speciálním boxu pomocí písku a soustavy zrcadel.

\section{Písek pod drobnohledem - překva- pivá krása písečných zrn}

Badatelský rozměr výstavy reprezentovaly velkoplošné fotografie písečných zrnek ve druhém sále. Kolekce fotografií vznikla na Přírodovědecké fakultě Univerzity Karlovy v Praze. Byly vytvořeny unikátní metodou kombinace světelné a elektronové skenovací mikroskopie, která byla poprvé odzkoušena P. J. Juračkou v praxi právě na píscích v roce 2015 v rámci Semináře vědecké fotografie.

Pro účely naší výstavy byla vybrána kolekce písků biogenního původu, jež byla postupně zdokumentována díky zápalu a trpělivosti kolegů př́rodovědců z Katedry ekologie a životního prostředí Přírodovědecké fakulty Univerzity Karlovy. Každé vybrané zrnko muselo být nejprve nasnímáno až ve dvou stech různých rovinách ostrosti; získané snímky se poté prolnuly vždy do jednoho, celkově ostrého. Následně se každé zrnko (nalepené na hliníkovou minci a pozlacené v argonové plazmě) oskenovalo elektronovým mikroskopem. Posledním krokem bylo pak propojení této fotografie se zcela výjimečnou kresbou přes skládanou fotografii ze světelného mikroskopu. Vznikl tak barevně i strukturně přiměřeně
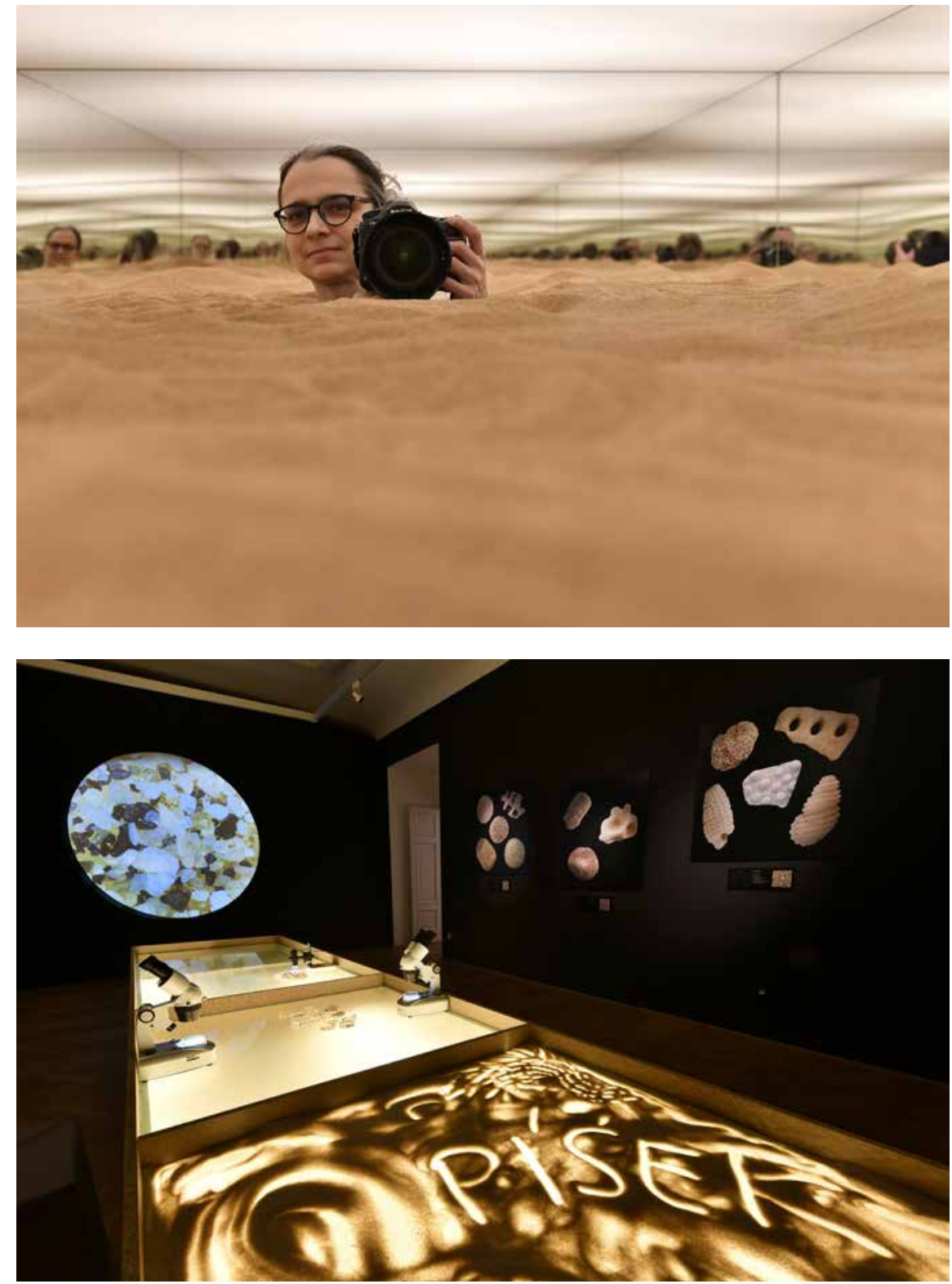

věrný obraz toho, jak takový písek vypadá. Většina vybraných zrnek pocházela z plážových písků přivezených z Thajska, ostrovů Bali a Lombok v Indonésii, ostrovu Faial náležícího k souostroví Azory, řecké Kréty či baleárské Menorcy. Návštěvníci měli prostřednictvím vystavených fotografií možnost poznat, jak nádherně vypadají mnohonásobně (až 460x) zvětšená zrnka písku, tvořená vápnitými schránkami dírkonošců, ostnů ježovek, schránkami plžů a mechovek či drobnými úlomky korálů.

O skryté kráse světa písku se návštěvníci kromě fotografických záznamů mohli přesvědčit i na vlastní oči. Ve výstavních prostorech byly dva binokulární mikroskopy s různorodými vzorky písku k pozorování, a také USB mikroskop, který promítal obraz zvětšeného písku na stěnu výstavního sálu. Každý si tak mohl najít
Pohled do „nekonečné pouště" foto: Z. Vařilová, Muzeum města Ústí nad Labem, 2020

Druhý sál věnovaný mikrosvětu s velkoplošnými fotografiemi zrnek pisků a podsvíceným stolem s možností mikroskopování a malování do písku. foto: J. Preclík, Muzeum města Ústí nad Labem, 2020 

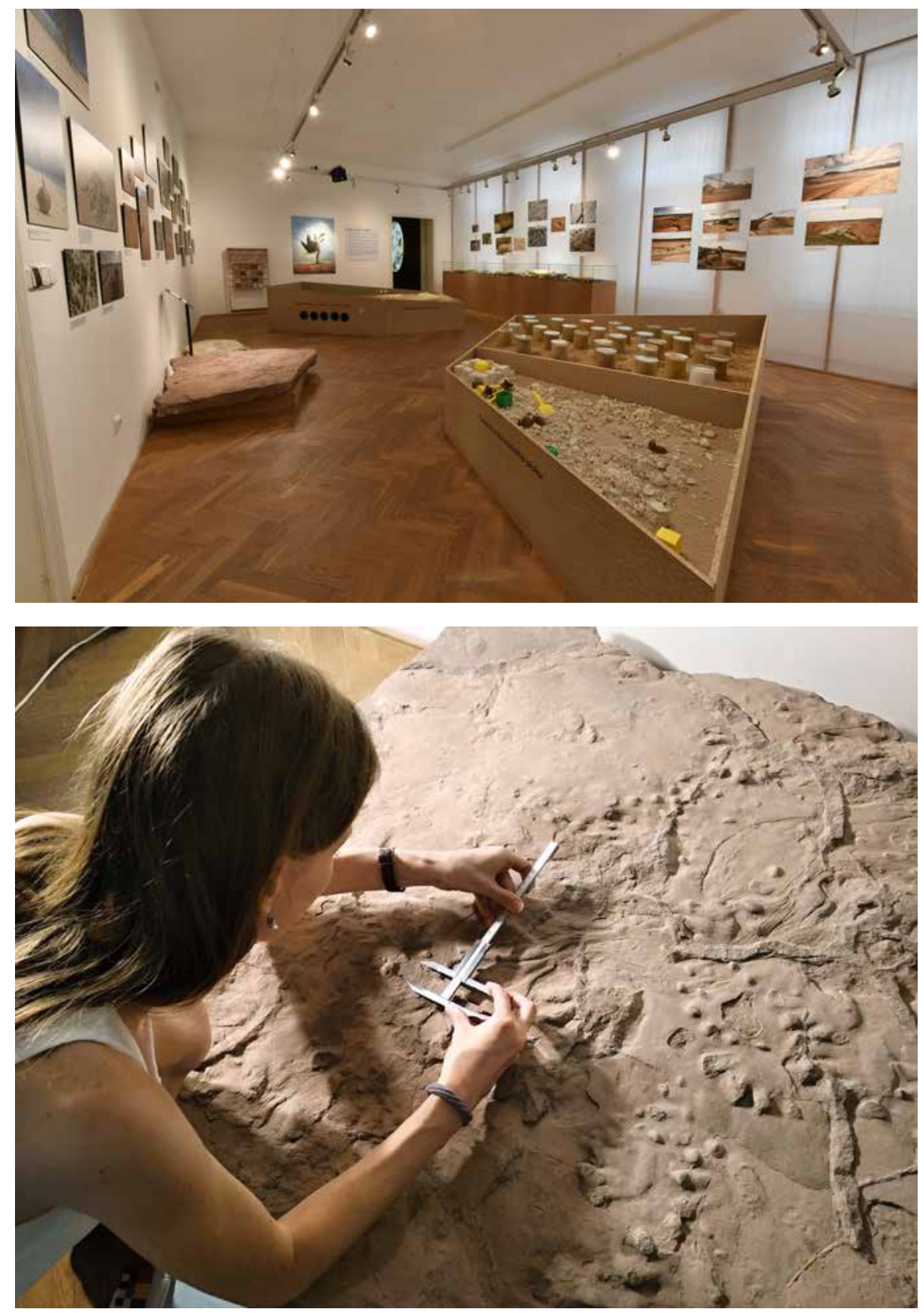

Tretí sál s více dílčími tématy "Život a stopy v pisku” a "Písek užitečný" predstavil vzácné paleontologické exponáty a vzorky písku z českých pískoven. foto: J. Preclik, Muzeum města Ústí nad Labem, 2020

Instalace velké kamenné desky dala muzejníkům zabrat. Prímo ve výstavě pak tento exponát podrobně zdokumentovali paleontologové z MZM $v$ Brně, kteří se věnují problematice fosilních stop. Kromě otisků permského čtvernožce, zde byly zachovány také fosilní polygonální praskliny nebo stopy po činnosti dalších drobných organismů, kteři $v$ jezerním písečném dně hledali potravu. foto: Z. Vařilová, v písečné hromádce jedinečné zrnko, pořádně ho prozkoumat a ukázat ostatním. Tvořivé zpestření pak umožnila druhá část prosvíceného stolu s nasypaným pískem, do kterého bylo možné kreslit.

\section{Písek jako otevřená kronika historie Země, stačí se jen začíst...}

Rozsáhlá území tvořená pískem mohou na první pohled působit jako sterilní a nehostinné prostředí. Zdání však klame a třeba rozpálené pouštní písky se staly domovem mnoha tvorů a rostlin. Také písčitá dna řek, jezer a moří obývají různé druhy vodních živočichů. A nejinak tomu bylo i v dávné minulosti. A díky tomu mohou být $\mathrm{v}$ písku zachovány fosilní schránky, kostry pravěkých tvorů a jiné stopy po dávném životě. Třetí sál byl proto věnován "stopám v písku“, těm prehistorickým i těm současným.

Ve vitrínách byly představeny paleontologické vzorky z naší republiky i zahraničí, zapůjčené z několika muzeí a soukromých sbírek. Tyto stopy po životě, obtisklé do písku a staré až 450 milionů let, mají fascinující tvary a pouze latinská jména jako Protovirgularia, Zoophycos, Skolithos, Thalassinoides, Asterosoma nebo Paleodictyon. V ČR byly na naší výstavě poprvé společně vystavené veřejnosti. Nechyběl ani přesný odlitek stopy tříprstého dinosaura, nalezené $\mathrm{v}$ dlažbě Botanické zahrady v Praze-Troji v roce 2010, jedinečný originál zkamenělé stopy po obřím mořském mlži připomínající zkamenělou páteř z úbočí Nořičí hory (Radhostium carpaticum) či nejstarší mravkolví trychtýř z jižního Polska, který vznikl současně s vyhynutím trilobitů.

Rozhodně nejtěžším (přes půl tuny vážícím), poprvé veřejně vystaveným, ale také nejméně probádaným exponátem celé výstavy byl paleontologický vzorek zapůjčený ze sbírek Národního muzea v Praze. Velká deska z jemnozrnného pískovce pochází z německého lomu Brombach u Tambachu a zachovaly se na ní stopy čtvernožce Ichniotherium sphaerodactylum, který žil přibližně před 280 mil. let a byl pravděpodobně předchůdcem dnešních plazů. Tento exponát při instalaci prověřil nejenom sílu ústeckých muzejníků, ale i nosnost podlahy ve výstavním sále.

\section{"Sypké zlato"}

Na výstavě nechybělo ani aktuální téma těžby a využití písku. Jde totiž o významnou nerostnou surovinu, která je nepostradatelná $\mathrm{v}$ mnohých průmyslových odvětvích. Používá se především ve stavebnictví jako součást betonu, asfaltu, ve sklářském průmyslu (především nejčistší křemenné písky s velmi nízkým obsahem železa a jiných příměsí), ve slévárenství či v keramickém průmyslu. Většina světových zásob pitné vody, ropy a plynu je uložena $\mathrm{v}$ rezervoárech tvořených písečnými uloženinami. Písky 
jsou také nepostradatelnou surovinou při výrobě aut, mikročipů, solárních panelů či chytrých telefonů. $V$ neposlední řadě jsou rovněž zdrojem oxidu křemičitého, který nalezneme ve víně, $\mathrm{v}$ čisticích prostředcích, papíru, $\mathrm{v}$ zubních pastách, v kosmetice a dalších výrobcích, které používáme každý den. Podle statistik uváděných $\mathrm{v}$ tisku jeho spotřeba stoupla za posledních 20 let více než trojnásobně, ročně se nyní na celém světě spotřebuje až 50 miliard tun písku. Zdroje využitelného písku jsou však omezené a lidé ho vytěží výrazně více, než kolik se ho do prírody dostane zpět přirozenými procesy, tedy erozí a zvětráváním hornin. Celosvětově ho začíná být akutní nedostatek, je proto př́iznačně nazýván „sypké zlato“. Stavební boom zejména $\mathrm{v}$ asijských zemích způsobil vznik ilegálního obchodu s touto surovinou, a dokonce vytvoření „písečných mafiii“, které ve velkém drancují pláže a koryta řek.

Součástí tematického koutku $\mathrm{k}$ těžbě byla prezentace především českých pískoven. Hlavní exponát tvořil soubor 33 druhů písků z činných lomů, získaný v letech 2011-2015 v rámci projektu, jehož řešitelem byl Výzkumný ústav anorganické chemie a Univerzita Jana Evangelisty Purkyně v Ústí nad Labem. Celosvětově nejslavnější český písek pak reprezentoval tzv. uzamčený písek z lomu Střeleč. Jde o zvláštní materiál, který z hlediska mechanických vlastností leží na přechodu pískovce a písku. Křemenná zrna uzamčeného písku do sebe dobře zapadají, tento písek tak vydrží velký tlak. Mezi zrny uzamčeného písku není však žádný tmel, a proto lze jednotlivá zrna velmi snadno odtrhnout od sebe. Krátké video prezentované ve spolupráci s časopisem Vesmír ukazovalo divákům, jak deseticentimetrová kostka uzamčeného písku bez problému unese osobní auto (namáhání tlakem), ale zároveň se tatáž kostka rozpadne samovolně během chvilky ve stojaté vodě. V písku ze Střelče navíc vznikají během pouhých minut zmenšeniny skalních útvarů, které známe $\mathrm{z}$ národních parků po celém světě. Pozorování uzamčeného písku tak napomohlo rozřešit otázku
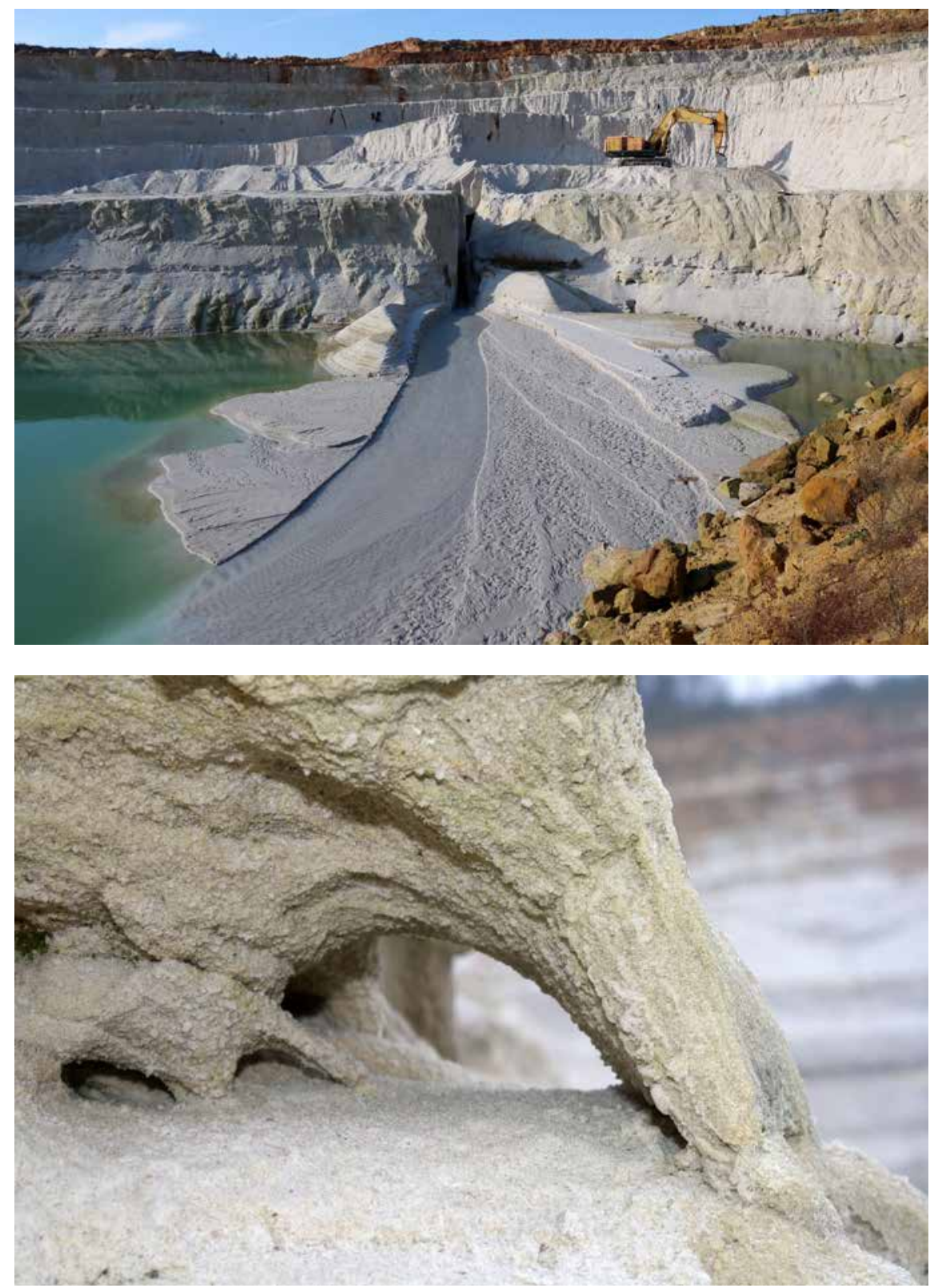

vzniku pískovcových forem, jako jsou velkolepé skalní brány či skalní hřiby. Prezentovanou tématiku doprovázelo kromě ilustračních krátkých videí také množství dokumentačních obrázků.

Třetí výstavní sál byl přes svůj odborný obsah zároveň nejhravější částí celé výstavy a vyřádili se tu hlavně nejmenší návštěvníci. Interaktivní část byla tvořena stolem s promítáním stop různých zvířat a s možností otisknout si vypreparovaná kopýtka či nohy ptáků do skutečného písku, mozkové buňky potrápila hádankářská otočná mozaika „Kdo zanechal stopy v písku“", nebo možnost pohrát si s kinetickým pískem. Mnohé překvapil i haptický prvek s hádankou, který poukázal na fakt, že písek je na omak podobný jiným běžným materiálům, jako soli, máku nebo rýží.
Lom Střeleč, kde je těžen sklářský písek, se stal největší prírodní laboratoří. Princip zákonité souhry mezi tlakovým polem v piskovci a působícími erozními činiteli zde prokázal výzkumný tým Jiřiho Bruthanse, výsledky byly $v$ roce 2014 publikovány $v$ prestižním časopise Nature. foto: M. Filippi, Muzeum města Ústí nad Labem, 2020 

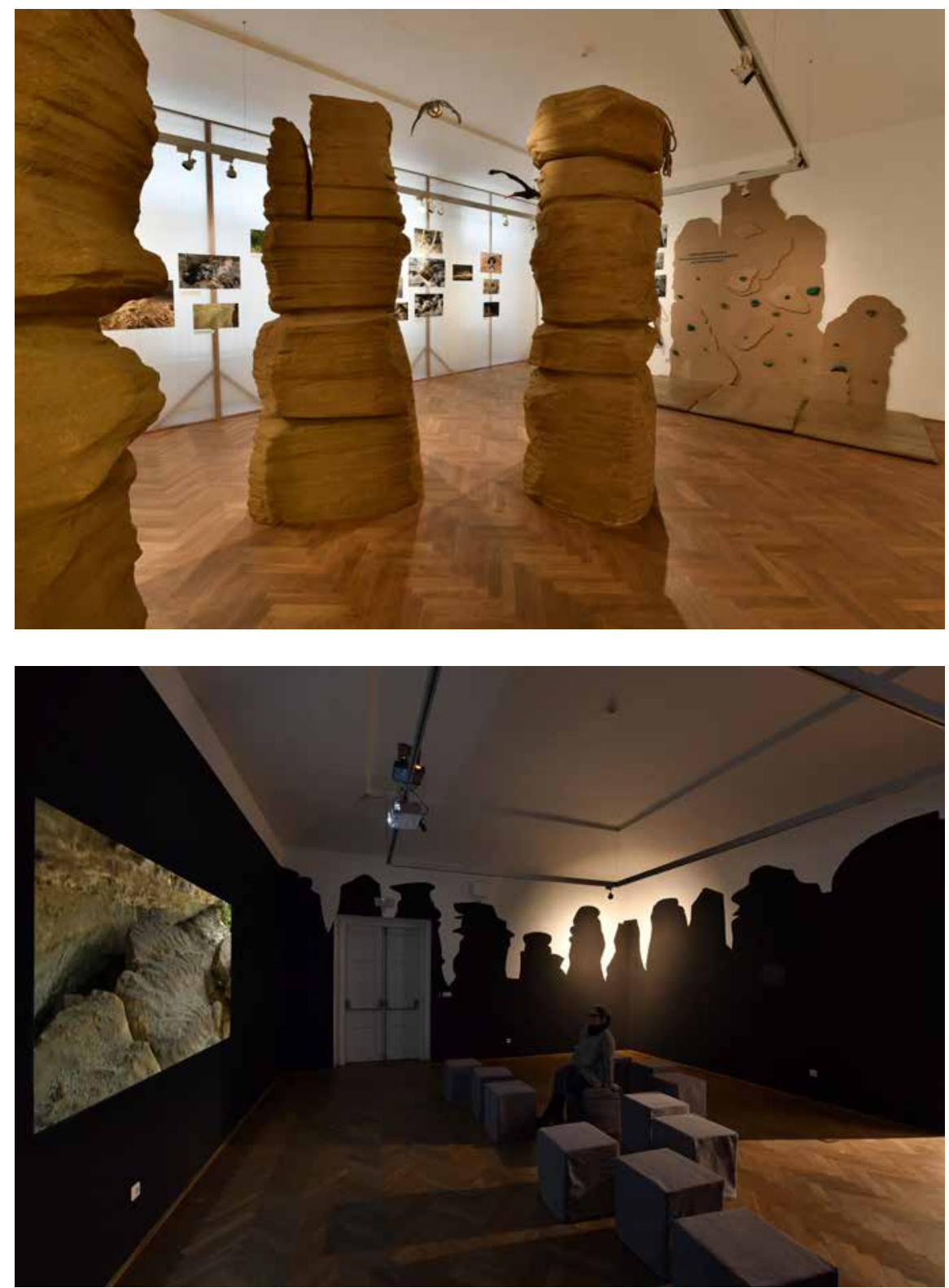

Pískovcová krajina Českého Švýcarska byla predstavena ve čtvrtém výstavním sále se skalními věžemi a lezeckou stěnou pro děti.

foto: J. Preclík, Muzeum města Ústí nad Labem, 2020

Skalní kinosál s tematickými dokumentárními filmy.

foto: J. Preclík, Muzeum města Ústí nad Labem, 2020

\section{Krajina z písku zrozená}

Poslední dva výstavní sály a část přilehlé chodby byly pak věnovány Českosaskému Švýcarsku (především labským pískovcům). Tato část výstavy o pískovcích skvěle doplnila celoroční akce ke kulatému 20. výročí založení zdejšího národního parku. Na fotografiích a ve vitrínách byly ukázky pozůstatků po ukládání písku na křídovém mořském dně a zkamenělé otisky druhohorního života, ale i roztodivné tvary povrchu, vzniklé postupnou erozí a zvětráváním zdejšího pískovce. Sálu dominovaly tři obří "pískovcové" věže - věrný obraz skutečných pískovcových skal, jejichž povrch opět pokrýval opravdový písek. A nechyběla ani horolezecká stěna pro nejmenší návštěvníky, která byla nejenom skvělým prvkem pro podnícení dětí $\mathrm{k}$ fyzické aktivitě, ale také spolu s historickými fotografiemi připomínala skutečnost, že zdejší oblast je kolébkou pískovcového horolezení.

V poslední páté výstavní místnosti, tzv. skalním kinosále, pak byly promítány dva dokumentární filmy z cyklu Cesta ke kameni, na kterých se podíleli autoři výstavy a jež celou výstavu tematicky zastřešily. Jeden o putování pískového zrnka byl věnovaný Českému Švýcarsku („,Kameny v pohybu“) a druhý byl zkrácenou verzí filmu o pravěkých stopách $\mathrm{v}$ písku („Zkamenělé stopy“). Přilehlá chodba pak obsahovala množství informací o vývoji a změnách pískovcové krajiny (Skály z pisku stvořené v písek se obrátí), veduty Českosaského Švýcarska i prezentaci regionálního sklářského průmyslu či archeologických nálezů z pískovcových převisů (Poklady skryté v pisku).

\section{Písek jako prostředník $k$ meditaci a rozjímání}

Výstava „Písky známé i neznámé“ pronikla i do venkovních prostor muzea. $\mathrm{V}$ atriu muzea vznikla $\mathrm{v}$ letní sezóně meditační ZENová zahrada - stylizovaná krajina tvořená kameny a upraveným hrabaným pískem. V rušném centru města Ústí nad Labem bylo tedy možné nejenom trávit čas $\mathrm{v}$ nekonečné poušti, ale také zpomalit a zklidnit mysl v neklidné době. Miniaturní zenové zahrádky byly pak návštěvníkům $\mathrm{k}$ dispozici pro vlastní meditační aktivity na stolech $\mathrm{v}$ muzejní kavárně.

\section{Písek jako synonymum pro zvídavost, hravost i tvorbu}

K výstavě vyšel dvojjazyčný (česko-anglický) katalog se základními texty a množstvím fotografií. Byla vydána obsáhlá monografie Geologie Českosaského Švýcarska. Pro děti byly ve výstavě k dispozici pracovní listy s úkoly, v době jarního a podzimního pandemického uzavření muzea vznikly i tematické online kvízy a hry. V době rozvolnění opatření proběhly také dva výlety do zdejších pískovcových skal a oddělení pedagogiky připravilo 
o letních prázdninách akce pro děti nazvané „Pískohraní. V neposlední řadě s pískovci úzce souvisel i exponát měsíce července, kterým bylo proželeznění $\mathrm{v}$ pískovcích, jež svou tvarovou pestrostí připomínalo našim předkům kamenné růže nebo létající stroje neznámých vesmírných civilizací.

A nejvíce potěšující bylo, že výstava na nevšední téma měla nakonec úspěch u malých i velkých návštěvníků. Nejenom děti v ní díky hravým prvkům trávily hodiny a hodiny času, ostatně některé $z$ nich navštívily výstavu opakovaně.

\section{Úspěch i pomíjivost písku}

Anglický romantický básník William Blake před více než 200 lety napsal: „Spatřit svět v zrnku písku a nebe v divoké květině. Zachytit nekonečno v dlani a věčnost v jedné hodině." Tento citát spolu s dalšími zdobil chodbu

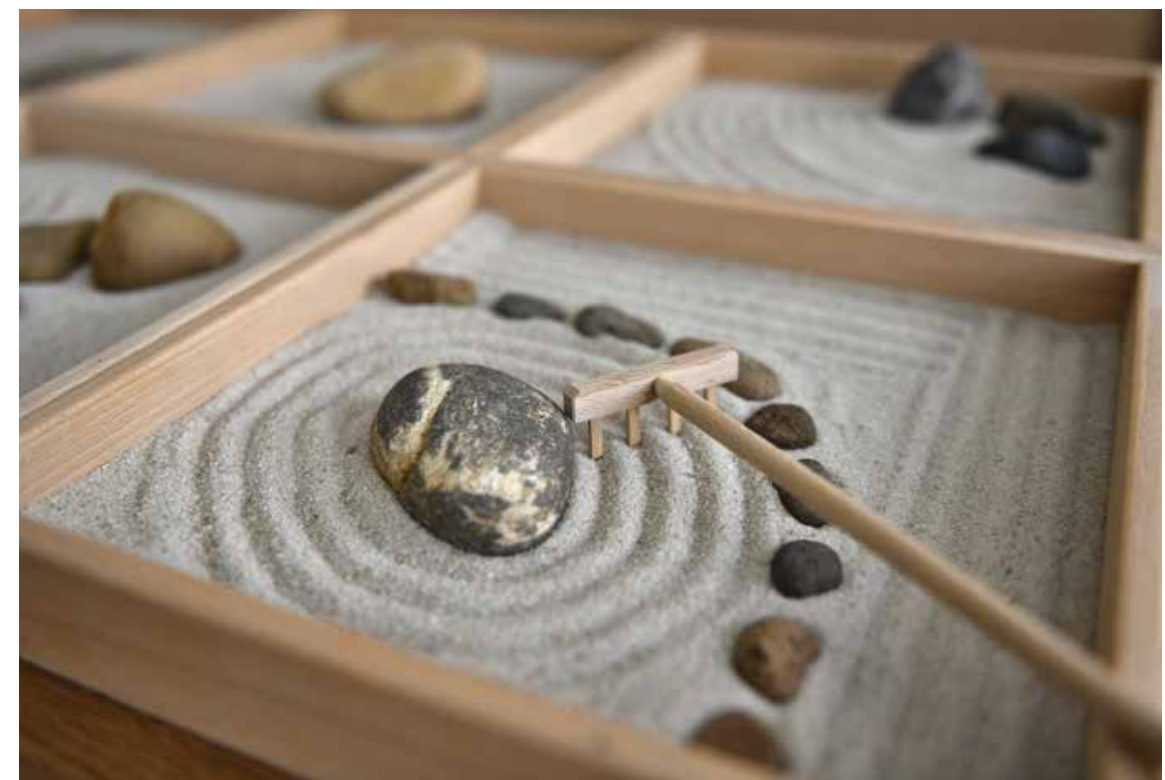

u vstupu do výstavy a vybízel k zamyšlení nad významem obyčejných věcí i jejich dočasnosti. Přestože byla výstava Písky známé i neznámé oceněna jako nejlepší výstava roku 2020 cenou Gloria Musaealis, vcelku už ji nikdy neuvidíte. Ale nakonec je to příznačné - písečná výstava sama byla stejně pomíjivá jako všechny výtvory z písku. Exponáty se již
Malé ZENové zahrádky pro veřejnost - pomíjivá krása tvorby z písku. foto: J. Preclík, Muzeum města Ústí nad Labem, 2020

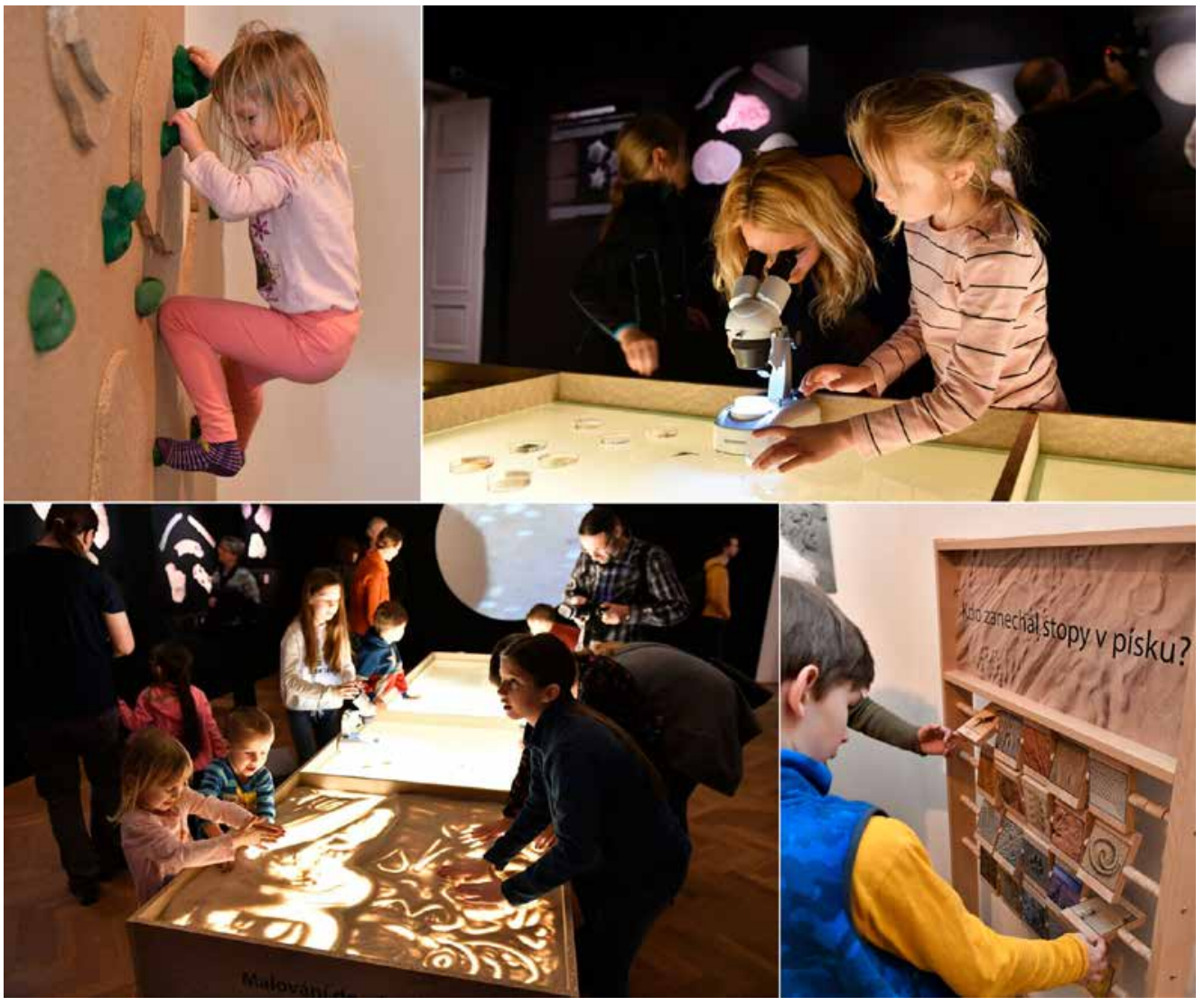

Přiklady interaktivních prvků z výstavy: horolezecká stěna pro děti, mikroskopování písků, malování do písku a poznávačka stop. foto: J. Preclík, Muzeum města Ústí nad Labem, 2020 
navrátily zpět do muzejních depozitářu a soukromých sbírek, písečné duny posloužily v Umělecké galerii Bubec v Praze, modely pískovcových věží tvoří nyní tematické kulisy v prostorách Plšíkovy učebny u Správy Národního parku České Švýcarsko. Samostatná část výstavy „Písek pod mikroskopem“ věnovaná mikrofotografiím písečných zrnek bude dále putovat po výstavních prostorách a část věnovaná životu a stopám $\mathrm{v}$ písku by měla být $\mathrm{v}$ prrištím roce prezentována $\mathrm{v}$ pražské zoologické zahradě. Vír událostí a neustálých změn tak rozfoukal písečnou výstavu na prvočinitele, které nám ji budou nadále připomínat na rozmanitých místech.

\section{Literatura a odkazy:}

BRUTHANS Jiří, SOUKUP Jan, Vaculíková Jana, FILIPPI Michal, SCHWEIGSTILLOVÁ Jana, MAYO Alan L., MAŠÍN David, KLETETSCHKA Gunther, ŘIHOŠEK Jaroslav. Sandstone landforms shaped by negative feedback between stress and erosion. - Nature Geoscience, 2014, 7(8): 597-601.

JURAČKA Petr Jan. Na pláže, pojd'me na pláže... tam se všechno ukáže. - Vesmír 99, 290, 2020/5: 290-291.

VAŘILOVÁ Zuzana, MARTÍNEK Karel, JURAČKA Petr Jan, MIKULÁŠ Radek, BRUTHANS Jiří. Písky známé i neznámé aneb Fascinující svět obyčejného písku: doprovodná publikace $k$ výstavě / Sands: explicit and enigmatic, The fascinating world of ordinary sand: accompanying text to the exposition. Doprovodná publikace k výstavě, Ústí nad Labem: Muzeum města Ústí nad Labem, 2020, 72 s. (č/angl)

VA ŘILOVÁ Zuzana ed. Geologie Českosaského Švýcarska. Ústínad Labem:Správa Národního parku České Švýcarsko, Muzeum města Ústí nad Labem a Ústecký kraj, 2020, 575 s.

Online hra s tématy k výstavě: Atlas písků, Krajiny, Stopy, Mikrosvět, Pískovce: http://www.pisek.8u.cz/ 